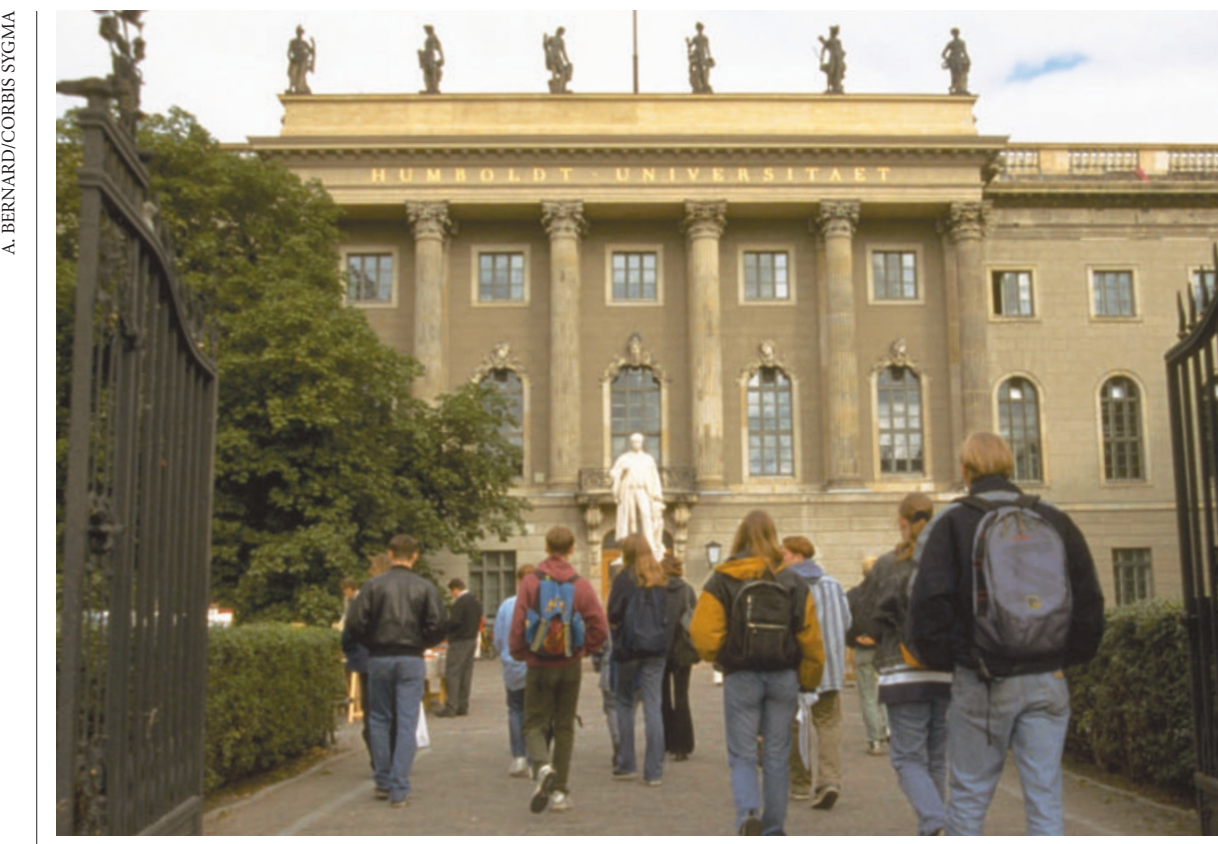

Humboldt University of Berlin: Germany is concerned over the global standing of such institutions.

\title{
Universities battle for extra funds in bid to boost quality
}

\section{Quirin Schiermeier, Munich}

Germany's top universities are being asked to compete for top-up grants from the federal government to help them pack more of a punch internationally.

Five winning institutions will each get extra funding of $€ 50$ million (US\$60 million) every year for five years from 2006, in a bold scheme designed to help them compete on a global stage with the likes of Harvard University and the University of Tokyo.

A competition for the money will start in the summer, Germany's science minister Edelgard Bulmahn announced at a meeting in Berlin on 26 January. She called on all of Germany's 100 or so research universities to apply by setting out a plan of how they would use the money to improve teaching and research. The winners will be chosen next year by a committee of German and foreign researchers and administrators.

"We urgently need more money for research, but we also need more quality for our money," Bulmahn says.

Other participants at the meeting included Horst Störmer of Columbia University in New York, who won the 1998 Nobel physics prize, and Chancellor Gerhard Schröder, who said last month that Germany must do more to promote its élite universities (see Nature 427,271;2004).

The federal government has promised $€ 1$.25 billion to the competition. One option for finding the money is to sell part of the German central bank's gold reserves (see Nature 427, 386; 2004)
In 1996, the government launched a similar competition, called BioRegio, in which different regions of the country competed for biotechnology funding for grants and equipment. Policy-makers think that this initiative had some success in strengthening German biotechnology.

Critics argue that it will take more than a cash competition to reform the country's university system. "It is not sufficient that universities send around applications boasting how well they can perform," says Dagmar Schipanski, science minister of the east German state of Thuringia. She thinks it would be better just to give the money to the DFG, the country's main research funding agency, so that all researchers could compete for it.

But Peter Gaehtgens, president of the German Conference of University Rectors, says he is optimistic that the competition will help to increase the international standing of Germany's top universities. In a Chinese survey of research universities released last month, no German university came in the top 40.

"Fresh money is always welcome," says DFG president Ernst-Ludwig Winnacker. "But it takes more than that. German university laws still promote equality, rather than competition for the best students and young scientists."

Winnacker, Gaehtgens and the heads of several other research organizations meet with Bulmahn later this month to hammer out the details of the competition, and to discuss further steps that could be taken to modernize Germany's universities.

\section{Extinction meeting kicks off Japan's plans for networking}

David Cyranoski, Okazaki

East Asian researchers can sometimes feel cut off from the merry-go-round of small but prestigious meetings that help to further the careers of their colleagues in Europe and North America. Now a series of conferences in Japan aims to give these scientists similar benefits.

On 25-30 January, at the First Okazaki Biology Conference, 70 researchers from 10 countries met in the coastal city of Okazaki on Japan's main island to discuss the biology of species extinction.

The conference's organizers hope that it is the first of what will become a significant series, modelled loosely on the Gordon Research Conferences held in the United States. "There's nothing like the Gordon Conferences in this region," says Yoshitaka Nagahama, a developmental biologist at Okazaki's National Institute for Basic Biology, and chair of the series.

Motoya Katsuki, the institute's director, who thought up the idea of the conferences, says the plan is to bring together "many researchers who are climbing different sides of the same mountain and can't see one another".

The extinction meeting brought together specialists in long-term climate modelling, the geographical distribution of animals, and the origin and evolution of species.

But getting Japanese researchers to join the international networks that serve to build new fields of research won't be easy: much of the meaningful exchange at small meetings goes on informally in conversations between sessions. The organizers say that Japanese researchers sometimes fade into the background at such times, mixing mainly with one another.

Yoh Iwasa, a theoretical biologist at Kyushu University who helped to organize the meeting, concedes that "Japanese researchers are not used to getting involved". But he says that at the meeting they became more vocal as the week progressed, and he is optimistic about the future. "This was only the first one," he says.

A second meeting on species extinction is set for 2006, and Okazaki meetings are also planned for September to discuss organisms living in extreme conditions, and for March next year on reproduction. Many more could follow, the organizers say, if the model proves successful. 